\title{
Cancer preventive Effect of Morinda citrifolia (Noni) fruit juice against the AflatoxinB1-induced genotoxicity in human peripheral lymphocytes in vitro.
}

\author{
MD. SULTAN AHMAD, SHEEBA, AFSAR ALI AND KANCHAN B. RAI. \\ Department of Zoology, S.N. (P.G.). College, Azamgarh, U.P.276001
}

\begin{abstract}
Morinda citrifolia (Noni) has been used in folk medicine by Polynesians for over 2,000 years and is reported to have a broad range of therapeutic effects, including anticancer activity. The exact mechanism of action is unknown. The hypothesis is generated from the experiment that Morinda citrifolia possesses a cancer preventive effect at the initiative stage of carcinogenesis. The antigenotoxic potential of Noni juice (NJ) was demonstrated on the aflatoxin B1 induced genotoxicity. In vitro studies were carried on human lymphocyte culture. We have used chromosomal aberration (CA), sister chromatid exchange (SCE) and cell cycle kinetics (CCK) with and without $S_{9}$ mix. as markers in this experiments. Four doses viz., 200, 250, 300, $350 \mu \mathrm{l} / \mathrm{ml}$ per culture were selected and found that $\mathrm{NJ}$ significantly reduces the frequencies of chromosomal aberration, sister chromatid exchanges and enhances RI in vitro. It was also noticed that the antigenotoxic potential of NJ shows dose - response relationship. The results suggest that $\mathrm{NJ}$ was a potent anticarcinogen may contribute to the cancer prevention.
\end{abstract}

Key words: Morinda citrifolia (Noni), Noni Fruit juice (NJ), chromosomal aberration, Sister Chromatid Exchange, anticarcinogen.

\section{INTRODUCTION:}

Noni is the common name for Morinda citrifolia. It is a medicinal plant called Indian mulberry in India, bajitian in China, Nono in Tahiti, and noni in Hawaii (Morton J, 1992.). In India it is distributed throughout Tamil Nadu and Kerala in South India, especially coastal region and also in the Mangalore area of Karnataka. Among the medicinal plants discovered by the ancestors of Polynesians, Morinda citrifolia L(Noni) is one of the traditional folk medicinal plants that has been used for over 2000 years in Polynesia. It has been reported to have a broad range of therapeutic effects like anti-cancerous, antitumor, and have nutritional value. Noni has an abundance of micronutrients. It has also been used by the native Tahitians for over 2000 years as a nutritional supplement to treat diseases and promote general good health (Abbott \& Shimazu, 1985; Degener, O. 1973).

Noni plants have 160 identified chemicals, the major components are terpene, scopoletin, octoanoic acid, potassium, vitamin $\mathrm{C}$, terpenoids, alkaloids anthraquinones (such as nordamnacanthal, morindone, rubiadin, and rubiadin- $\square$-methyl ether anthraquinone glycosides), sitosterol, carotene, vitamin A, flavone glycosides, linoleic acid, alizarin, amino acids, cacubin, $L$-asperuloside, caproic acid, caprylicacid, ursolic acid, rutin, and a putative proxeronine polysaccharides, and alkaloids. Dr Neil Solomon summarized 15,000 cases of NJ users, and found the total effective rate of NJ on various health problems, including cancer to be $78 \%$ effective. NJ may possess a cancer preventive effect at the initiation stage of carcinogen and /or antioxidant activity.

The anticancer activity from alcohol-precipitate of Noni fruit juice (Noni-ppt on to lung cancer in c57 B1/6 mice has been presented in the 83 Annual Meeting of American Association for Cancer Research. The NJ significantly increased the life of mice up to $75 \%$ with implanted Lewis lung carcinoma as compared with the control mice (Hirazumi et al., 1994). It was concluded that the NJ seems to suppress tumor growth directly by stimulating the immune system (Hirazumi et al., 1996). Improved survival and curative effects occurred when Noni-ppt was combined with sub optimal doses of the standard chemotherapeutic agents such as adriamycin (Adria), cisplatin(CDDP), 5-flourouracil (5-FU) and vincristine (VCR), suggesting important clinical application of Noni-ppt as a supplemental agent in cancer treatment (Hirazumi and Furusawa, 1999). These results indicated that the Noni-ppt might enhance the therapeutic effect of anticancer drugs. Therefore, it may be a benefit to cancer patients by enabling them to use lower doses of anticancer drugs to achieve the same or even better results. Wang et al. (2002) demonstrated that the cytotoxic effect of Tahitian Noni Juice (TNJ) on cultured leukemia cell line at various concentrations. They also observed the synergistic effects of TNJ with known anticancer drugs. At a sub-optimal dose, both prednisolone and TNJ could induce apoptosis. When the dose of prednisolone was fixed, the dose of TNJ increased. Therefore TNJ is able to enhance the efficacy of anticancer drugs such as predinosolone. When a single dose of taxol induced a lower percentage of apoptosis in leukemia cells, TNJ enhanced the rate of apoptosis. Hiramatsu et al. (1993) reported effects of over 500 extracts from tropical plants on the K-Ras-NRK cells. The Ras oncogene is believed to be associated with the signal transduction in several human cancers such as lung, colon, pancreas, and leukemia. Two glycosides extracted from Noni-ppt were effective in inhibiting cell transformation induced by TPA or EGF in the mouse epidermal JB6 cell line. The inhibition was found to be associated with the inhibitory effects of these compounds on AP1 activity. The 
compounds also blocked the phosphorylation of c-Jun, a substrate of JNKs, suggesting that JNKs are the critical target for the compounds in mediating AP1 activity and cell information (Liu et al., 2001).

\section{MATERIALS AND METHODS:}

Experiment was performed using the technique of Moorehead et.al (1960), for metaphase chromosome analysis and for detection of chromosomal aberration analysis (CAs). Human lymphocyte cultures were set by adding $0.5 \mathrm{ml}$ of whole blood (from two adult and healthy donors, occupationally not exposed to mutagens) to $4.5 \mathrm{ml}$ of RPMI 1640 (Gibco, USA), antibiotics (Penicillin and streptomycin $100 \mathrm{IU} / \mathrm{ml}$ each; Hoechst) and L. Glutamine (1 mM; Gibco, USA). Lymphocytes were stimulated to divide by adding $0.1 \mathrm{ml}$ of phytohaemagglutinin- $\mathrm{M}$ (PHA- M, Gibco). The cultures were incubated at $37^{\circ} \mathrm{C}$ with $5 \% \mathrm{CO}_{2}$ for 72 hours in dark. Aflatoxin B1 at a final concentration of $50 \mu \mathrm{g}$ was added at 0 hour and kept for 24 , 48 and 72 hours of duration, which served as positive control. Subsequently, desired test chemical were added along with Aflatoxin B1 and the cultures were kept for 24, 48 and 72 hours. Noni juice and Aflatoxin B1 were prepared in DMSO. In the metabolic activation experiments cultures were treated with $S_{9}$ mix $\left(0.8 \mathrm{ml}\right.$.), the $S_{9}$ mix was freshly prepared as per the standard procedures of Maron and Ames (1983). The $S_{9}$ fraction was complemented by the addition of $5 \mu$ M NADP and 10 $\mu \mathrm{M}$ glucose -6 - phosphate just before use. Colchicines $(0.20 \mu \mathrm{g} / \mathrm{ml}$, Micro lab) were added to the cultures 2.5 hours prior to harvesting. The cells were collected by centrifugation $(10 \mathrm{~min}, 1200 \mathrm{rpm})$, hypotonic treatment $(0.075 \mathrm{M} \mathrm{KCl})$ was given for 10-12 min at $37^{\circ} \mathrm{C}$ and the recollected cells after centrifugation were fixed in methanol: acetic acid (3:1). DMSO and Aflatoxin B1 were uses as negative and positive controls, respectively. Preparation of slides, staining and scanning was done under code. A total of 300 well - spread metaphases were analyzed per treatment per duration for all types of chromatid and chromosome type of aberrations. Aberrations were scored as per Hundal, et al ( 1997). Analysis of SCE was carried out following the fluorescent plus Giemsa technique of Perry and Wolfs (1974). The cells in the cultures were exposes to 5bromo-2-de oxyuridine (BrdU $2 \mu \mathrm{g} / \mathrm{ml}$; Sigma) after 24 hours of initiation of culture. The test compounds with same concentrations as in the case of CA analysis were added together with the BrdU. To minimize photolysis of BrdU another 48 hours cultures were maintained in the dark. After $90 \mathrm{~min}$. of this pulse treatment the cells were spun down and the supernatant discarded. The cells were washed twice to remove any traces of the drug, phytoproducts and the liver metabolites. Finally the cell pellets were re-suspended in fresh medium supplemented with fetal calf serum, antibiotics and BrdU, and kept for another 24 hours in the dark at $37^{\circ} \mathrm{C}$.

One day old slides were stained in Hoechst 33258 stain (Sigma $0.5 \mu \mathrm{g} / \mathrm{ml}$ ), exposed to UV lamp (254 nm) for 30 min. and incubated in $2 \mathrm{X} \mathrm{SSC}(0.3 \mathrm{M} \mathrm{NaCl}, 0.03 \mathrm{M}$ Sodium citrate; $\mathrm{pH} 7.0)$ at $60^{\circ} \mathrm{C}$ for 90 min and stain for sister chromatid. The slides were coded prior to scoring and 50 well- spread metaphase cells were scanned per concentration and the number of exchanges scored (Hundal, et al., 1997). Cells undergoing $1^{\text {st }}\left(\mathrm{M}_{1}\right), 2^{\text {nd }}\left(\mathrm{M}_{2}\right)$ and $3^{\text {rd }}\left(\mathrm{M}_{3}\right)$ metaphase divisions were detected with BrdU - Harlequin technique for differential staining of metaphase chromosome by studying 200 metaphases for each combination and duration. The replication index (RI), an indirect measure of studying cell cycle progression, was calculated by applying the following formula (Tice, et al., 1976).

$$
\mathrm{RI}=\frac{\mathrm{M}_{1 \times 1}+\mathrm{M}_{2 \times 2}+\mathrm{M}_{3 \times 3}}{1(O N \mathrm{~N}}
$$

100

\section{RESULT AND DISCUSSION:}

Noni is a medicinal plant that has antioxidant activity, may protect individuals from free oxygen radicals and consequent lipid peroxidation. In this experiment we have notices that Aflatoxin B1 treatment caused aberrations from 30.50 to $60.0 \%$ as the durations increases, when NJ are used it reduces from 19.75 to $50.0 \%$ at lower concentration and 19.0 to $46.5 \%$ at the highest concentration (Table-1). When culture were augmented with $\mathrm{S}_{9}$ mix, effects of NJ has shown more effective in reducing the percent of aberration. The range and mean values of SCE get reduced with NJ in the absence as well in the presence of metabolic activation (Table-2). The replication indices, which are reduced due to Aflatoxin B1 treatment level (1.44), is elevated to 1.58 , thus bringing the cell proliferation nearly back to near about normal of 1.60 . The $S_{9}$ activation has follow the above trend (Table-3 ).

In general, consuming fruits and vegetables reduces free radicals induced oxidative damage and the consequent lipid peroxidation and therefore reduce the cancer risk (Wang and Leiher, 1995; Diplock et al., 1998). It is believed that fruits and vegetables are major sources for antioxidants (Weisburer et al., 1997; Nishikimi et al., 1972). Noni is a medicinal plant that helps the human in different health conditions. It was believed that the Noni fruit juice contained significant level of antioxidants. This has been proved scientifically by the analysis of NJ. The study was designed to measure how the NJ scavenged superoxide anion radicals (SAR) and quenched lipid peroxides (LPO) by TNB assay and LMB assay, respectively (Auerbach et al., 1992; Wang and $\mathrm{Su}, 2001$ ). SAR scavenging activity was examined in vitro by Tetrazolium nitroblue (TNB) assay. The SAR scavenging activity of NJ was compared to that of three known antioxidants; vitamins C, grape seed powder, and pyncogenol at the daily dose per serving level recommended by US RDA's or manufacturer's recommendations. Under the experimental conditions the SAR scavenging activity of NJ was shown to be 2.8 times that of vitamin C, 1.4 times 
that of pyncogenol and1.1 times that of grape seed powder. Therefore NJ has a great potential to scavenge reactive oxygen free radicals (Wang and $\mathrm{Su}, 2001$ ).

The major ingredient in $\mathrm{NJ}$ and fruit has been safely consumed in other parts of the world for several hundred years. The interactions of carcinogens, free oxygen radicals, and LPO may be changed by NJ. The mechanism of the cancer preventive effect of $\mathrm{NJ}$ needs further study.

In conclusion, on the basis of our preliminary data, $\mathrm{NJ}$ may possess a cancer preventive effect at the initiation stage of chemical carcinogenesis. It serves as a good liquid nutritional supplement. NJ may help to prevent cancer and other diseases, and maintaining overall good health.

\section{REFERENCE}

1. Abbott, I.A. nda C. Shimazu, 1985. The geographic origin of the plants most commonly used for medicine by Hawaiians. J Ethnopharmacol.14:213-222.

2. Auerbach BJ , Kiely JS, Cornicell JA, 1992. A spectrophotometric microtiter-based assay for the detection of hydroperoxy derivatives of linoleic acid. Anal Biochem; 201: 375-80.

3. Bruggnecate JT, 1992. Native plants can heal your wounds. Honolulu Star-Bulletin Local News Feb 2.

4. Crossen, PE. and Morgan, W.F, 1977. Analysis of human lymphocyte cell cycle time in culture measured by sister chromatid differential staining. Exp. Cell. Res. 104, 453-457.

5. Degener, O, 1973. In Plants of Hawaii National Park Illustrative of Plants and Custom of South Seas. Photo lithoprint reproduction, Braun-Brumfield, Inc. Ann Arbor, MI

6. Evans, HJ. 1984. Human peripheral blood lymphocytes for the analysis of chromosome aberrations in mutagen tests. In: Kiley, B.J., Legator, M., Nichols, W. and Ramel, C. (Eds). Handbook of mutegenicity test procedures. Elsevier, Amsterdam 40-427.

7. Fisher and Yats ,1963. Statistical tables for Biological Agricultural and Medical Research (6 $6^{\text {th }}$ Eds). Hafner. Pub. Co. New York.

8. Habrah, F.L. and M.B. Eveleth. 1996. Evaluation of the effectiveness of ancient Hawaiian medicine. Hawaii Med. J.25:

9. Heinicke, R.M. 1985. The pharmacologically active ingredient of Noni. Bulletin of the National Tropical Botanical Garden.

10. Heinicke, RM,. 2001. The Xeronine System. A New Biological System, 2000. Direct Source Publishing.

11. Hiramatsu T, Imoto M, Koyano T, Umezawa K, 1993. Induction of normal p henotypes in ras -trans fo rmed cells bydamnacanthal from Morinda citrifolia. Cancer Lett ; 73: 161-6.

12. Hirazumi A, Furusawa E, 1999. An immunomodulatory polysaccharide rich substance from the fruit juice of Morinda citrifolia (noni) with antitumour activity. Phytother Res; 13: 380-7.

13. Hirazumi A, Furusawa E, Chou SC, Hokama Y, 1996. Immunomodulation contributes to the anticancer activity of Morinda citrifolia (noni) fruit juice. Proc West Pharmacol Soc; 39: 7-9.

14. Hirazumi, A., E. Furusawa, S.C. Chow \& Y. Hokama. 1994. Anticancer activity of Morinda citrifolia (noni) in intraperitoneally implanted Lewis lung carcinoma in syngeneic mice. Proc. West. Pharmacol. Soc. 37: 145-146.

15. Hirazumi, A.Y. 1997. Antitumor Studies of a Traditional Hawaiian Medical Plant,Morinda citrifolia (Noni), in Vitro and in Vivo. University of Hawaii, Ph.D. Thesis.

16. Levand O, Larson HO. Some chemical constituents of Morinda citrifolia. Planta Med 1979; 36: 186-7.

17. Moorhead P.S, Nowell D.C, Mellnan W.J, Battips D.M, and Hungerford D.A. (1960). Chromosome preparations of leucocytes cultured from human peripheral blood. Exp. Cell Res, 20: 613-616.

18. Moorthy NK, Reddy GS 1970. Preliminary phytochemical and pharmacological study of Morinda citrifolia, Linn. Antiseptic; 67: 167-71.

19. Morton,J. 1992. The ocean-going noni, or Indian mulberry (Morinda citrifolia Rubiaceae) and some of it “colorfull"relatives. Econ. Bot.46(3): 241-256.

20. Peerzada N, Renaud S, Ryan P, 1990. Vitamin C and elemental compos ition of some bushfruits. J Plant Nutrition; 13: 787-93.

21. Perry P, and Wolffs. 1974. New Giemsa method for the differential staining of sister chromatids. Nature (London). 251, 156-158.

22. Seemann B. Flora V. A description of the plants of the Viti or Fiji islands with an account of their history, uses, and properties. London: L Reeve and Co; 1866. p 1865-73.

23. Simonsen JL, 1990. Note on the constituents of Morinda citrifolia.J.Chem. Soc; 117: 561-4.

24. Singh J, Tiwari RD 1976. Flavone glycosides from the flowers of Morinda citrifolia. J Indian Chem Soc; 53 : 424.

25. Singh Y, Ikahihifo T, Panuve M, Slatter C, 1984. Folk medicine in Tonga. A study on the use of herbal medicines for obstetric and gynacological conditions and disorders. J Ethnopharm; 12: 305-25.

26. Tice R, Schneider E.L, and Rary J.M 1976. The utilization of BrdU incorporation into DNA for the analysis of cellular Kinetics. Exp. Cell. Res. 102, 232-236.

27. Wang MY, Su C, Nowicki D, Jensen J, Anderson G, 2001. Protective effect of Morinda citrifolia in carbontetrachloride-induced liver injury model: A light and electron microscopics study. The Proceedings of the 
Eicosanoids and other Bioactive Lipids in Cancer, Inflammatory and Related Diseases, the 7th Annual Conference, Loews Vanderbilt Plaza, Nashville, Tennessee, USA.

28. Wang MY, Su C 2001. Cancer preventive effect of Mor inda citrifolia (Noni). Ann NY Acad Sci; 952: 161-8.

29. Wang MY, Su C. 2000. Cancer preventive effect of Morinda citrifolia. The proceedings of the Strang International Cancer Prevention Conference. New York.

30. Wang, M.Y. \& J.G. Liehr. 1995. Induction by estrogens of lipid peroxidation and lipid peroxide derived malondial dehyde-DNA adducts in male Syrian hamsters: role of lipid peroxidation in estrogen-induced kidney carcinogenesis. Carcinogenesis 16(8): 1941-1945.

31. Weniger B. Weniger, M. Haag Berrurier and R. Anton 1982. Plants of Haiti used as antifertility agents. Journal of Ethnopharmacology 6, pp. 67-84.

32. Whistler W, 1992. Tongan herbal medicine. Isle Botanica, Honolulu,Hawaii. p 89-90.

33. Whistler WA, 1985. Traditional and herbal medicine in the cook islands. J Ethnopharm; 13: 239-80.

34. Yuncker TG, 1943. In: The flora of Niue Island. Bernice P. Bishop Museum Bulletin, 178. Honolulu, Hawaii: Bishop Museum Press. 
Table-1. Analysis of C.A. after treatment of Aflatoxin B1 and NONI JUICE (NJ )in absence as well as presence of $\mathbf{S}_{\boldsymbol{9}}-$ mix in vitro.

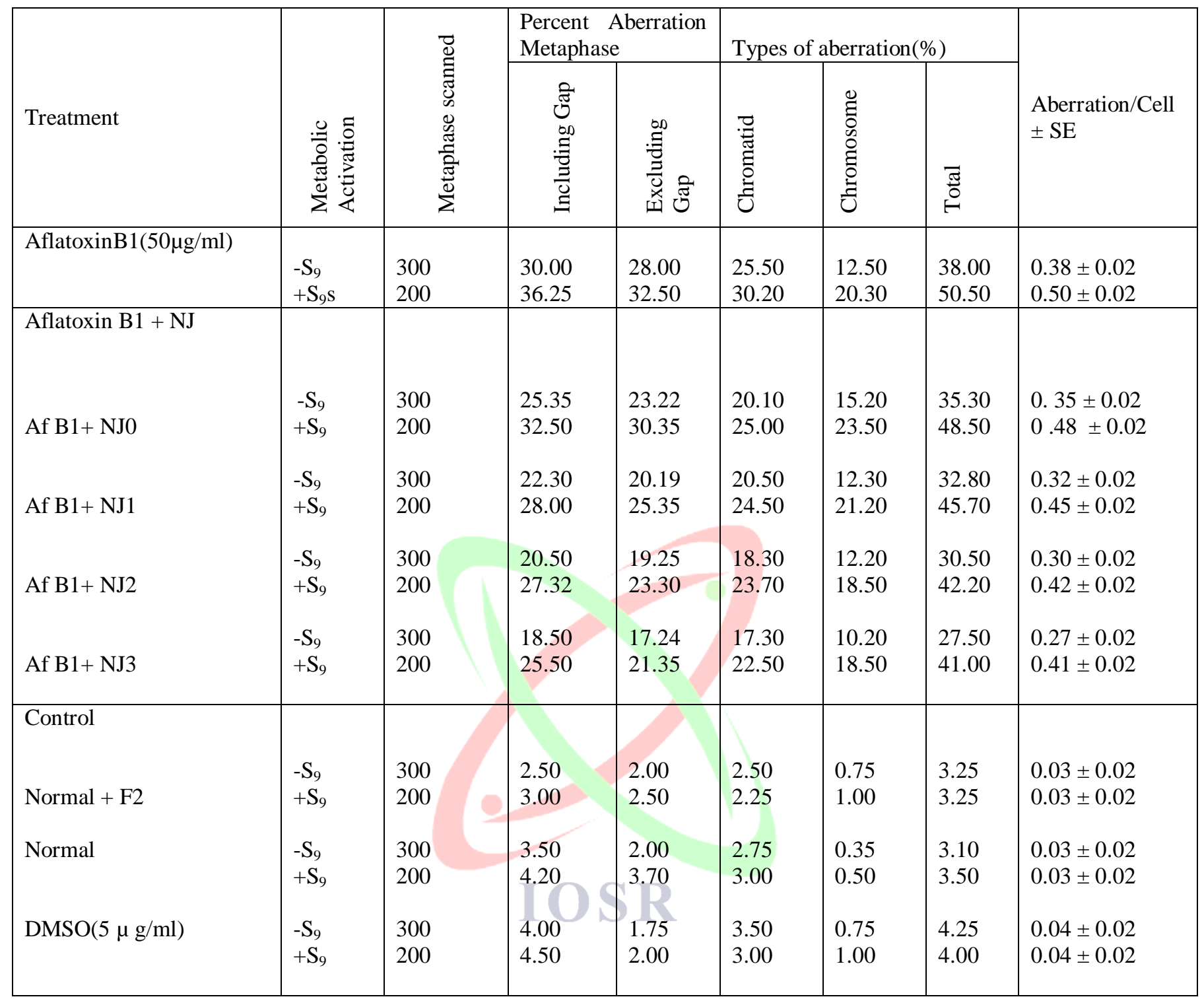


Table-2. Analysis of SCE, after treatment of Aflatoxin B1 and Noni juice (NJ) in vitro with and without metabolic activation.

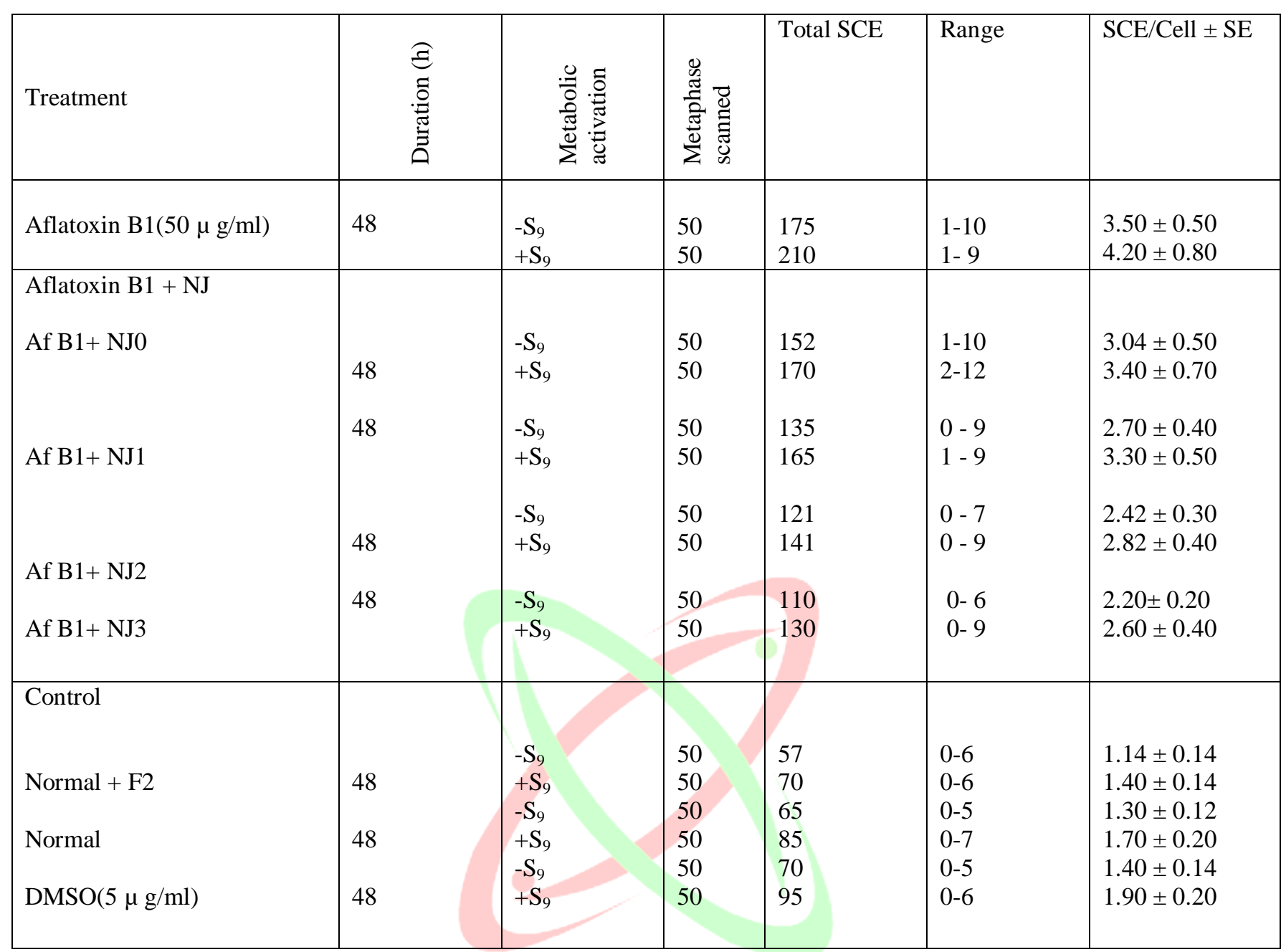


Table-3. Analysis of Cell cycle kinetic after treatment of Aflatoxin B1 and Noni juice(NJ) in vitro with and without metabolic activation.

\begin{tabular}{|c|c|c|c|c|c|c|c|}
\hline \multirow{2}{*}{ Treatment } & \multirow[b]{2}{*}{ Cell scored } & \multirow[b]{2}{*}{$\begin{array}{l}\text { Metabolic } \\
\text { activation }\end{array}$} & \multicolumn{3}{|c|}{ Percent Aberration Metaphase } & \multirow{2}{*}{$\begin{array}{l}\text { Replication } \\
\text { Index (RI) }\end{array}$} & \multirow[t]{2}{*}{$2 * 3$ Chi square test } \\
\hline & & & M1 & M2 & M3 & & \\
\hline $\begin{array}{lll}\begin{array}{l}\text { Aflatoxin } \\
\mathrm{g} / \mathrm{ml})\end{array} & \text { B1(50 } & \mu \\
\end{array}$ & $\begin{array}{l}200 \\
200\end{array}$ & $\begin{array}{l}-\mathrm{S}_{9} \\
+\mathrm{S}_{9}\end{array}$ & $\begin{array}{l}54 \\
57\end{array}$ & $\begin{array}{l}39 \\
35\end{array}$ & $\begin{array}{l}04 \\
05\end{array}$ & $\begin{array}{l}1.44 \\
1.42\end{array}$ & $\begin{array}{l}\text { Significant } \\
\text { Significant }\end{array}$ \\
\hline $\begin{array}{lll}\text { Aflatoxin } & \text { B1 } \\
\text { Flavonoids } & & +\end{array}$ & & & & & & & \\
\hline $\mathrm{Af} \mathrm{B} 1+\mathrm{NJ} 0$ & $\begin{array}{l}200 \\
200\end{array}$ & $\begin{array}{l}-\mathrm{S}_{9} \\
+\mathrm{S}_{9}\end{array}$ & $\begin{array}{l}51 \\
53\end{array}$ & $\begin{array}{l}38 \\
36\end{array}$ & $\begin{array}{l}08 \\
07\end{array}$ & $\begin{array}{l}1.51 \\
1.46\end{array}$ & $\begin{array}{l}\text { Signficant } \\
\text { Signficant }\end{array}$ \\
\hline Af B1+ NJ1 & $\begin{array}{l}200 \\
200\end{array}$ & $\begin{array}{l}-\mathrm{S}_{9} \\
+\mathrm{S}_{9}\end{array}$ & $\begin{array}{l}52 \\
54\end{array}$ & $\begin{array}{l}37 \\
38\end{array}$ & $\begin{array}{l}09 \\
12\end{array}$ & $\begin{array}{l}1.53 \\
1.66\end{array}$ & $\begin{array}{l}\text { Signficant } \\
\text { Signficant }\end{array}$ \\
\hline Af $\mathrm{B} 1+\mathrm{NJ} 2$ & $\begin{array}{l}200 \\
200\end{array}$ & $\begin{array}{l}-\mathrm{S}_{9} \\
+\mathrm{S}_{9}\end{array}$ & $\begin{array}{l}48 \\
50\end{array}$ & $\begin{array}{l}40 \\
42\end{array}$ & $\begin{array}{l}13 \\
08\end{array}$ & $\begin{array}{l}1.67 \\
1.58\end{array}$ & $\begin{array}{l}\text { Not Signficant } \\
\text { Signficant }\end{array}$ \\
\hline Af B1+ NJ3 & $\begin{array}{l}200 \\
200\end{array}$ & $\begin{array}{l}-\mathrm{S}_{9} \\
+\mathrm{S}_{9}\end{array}$ & $\begin{array}{l}49 \\
51\end{array}$ & $\begin{array}{l}36 \\
40\end{array}$ & $\begin{array}{l}15 \\
09\end{array}$ & $\begin{array}{l}1.66 \\
1.58\end{array}$ & $\begin{array}{l}\text { Signficant } \\
\text { Signficant }\end{array}$ \\
\hline $\begin{array}{l}\text { Control } \\
\text { Normal + NJ } \\
\text { Normal } \\
\text { DMSO }(5 \mu \mathrm{g} / \mathrm{ml})\end{array}$ & $\begin{array}{l}200 \\
200 \\
200\end{array}$ & & $\begin{array}{l}40 \\
41 \\
42\end{array}$ & $\begin{array}{l}35 \\
37 \\
36\end{array}$ & $\begin{array}{l}18 \\
15 \\
14\end{array}$ & $\begin{array}{l}1.64 \\
1.60 \\
1.56\end{array}$ & $\begin{array}{l}\text { Not Signficant } \\
\text { normal }\end{array}$ \\
\hline
\end{tabular}

